\title{
PALM2 Gene
}

National Cancer Institute

\section{Source}

National Cancer Institute. PALM2 Gene. NCI Thesaurus. Code C158481.

This gene may be involved in modeling of the actin cytoskeleton. 